JURNAL PLANS

Penelitian Ilmu Manajemen \& Bisnis

Vol. 10 No. 1 Maret 2015

\title{
PENGARUH KARAKTERISTIK PEKERJAAN DAN KARAKTERISTIK ORGANISASI TERHADAP KEPUASAN KERJA KARYAWAN PT. BANK MUAMALAT INDONESIA Tbk. KANTOR CABANG UTAMA PEMATANGSIANTAR
}

\author{
Nurul Wardani \\ Dosen Jurusan Manajemen Fakultas Ekonomi Universitas Negeri Medan \\ Ahmad Fadhila \\ Alumni Jurusan Manajemen Fakultas Ekonomi Universitas Negeri Medan
}

\begin{abstract}
Abstrak
Penelitian ini bertujuan untuk mengetahui pengaruh karakteristik pekerjaan dan karakteristik organisasi terhadap kepuasan kerja karyawan PT. Bank Muamalat Indonesia Tbk. Kantor Cabang Utama Pematangsiantar. Populasi dalam penelitian ini adalah 32 orang karyawan dan seluruh populasi dijadikan sampel. Pengujian yang digunakan adalah uji kualitas data dan uji asumsi klasik. Pengujian hipotesis menggunakan analisis regresi linear berganda, uji $F$ dan Uji t. Dari hasil uji validitas diperoleh $r$ hitung $>r$ tabel untuk masing-masing item pertanyaan dan uji reliabilitas angket diperoleh alpha cronbach masing-masing variabel yaitu 0,694 untuk variabel X1, 0,819 untuk variabel X2, serta 0,828 untuk variabel $Y$. Nilai ini lebih besar dari taraf signifikan $r$ tabel yaitu 0,3494. Analisis data masing-masing variabel diperoleh persamaan regresi berganda $Y=0,240+0,531 X_{1}+0,609$ $X_{2}+$ e. Diperoleh nilai $R^{2}$ sebesar 0,602, yang berarti X1 dan X2 menjelaskan pengaruh terhadap variabel $Y$ sebesar 60,2\% sedangkan sisanya dijelaskan variabel lain diluar penelitian. Uji parsial yang dihasilkan masing-masing variabel bebas berpengaruh terhadap variabel terikat dengan signifikansi penelitian lebih kecil dari 0,05, serta hasil perhitungan uji-Simultan sebesar 21,913 dengan $f$ tabel 3,128 yang artinya $F_{\text {hitung }}>F_{\text {tabel }}$ dengan level of significant $(\alpha)$ 0,000 < 0,05, yang artinya hipotesis diterima yaitu karakteristik pekerjaan dan karakteristik organisasi secara bersama-sama berpengaruh signifikan terhadap kepuasan kerja karyawan PT. Bank Muamalat Indonesia Tbk. Kantor Cabang Utama Pematangsiantar.
\end{abstract}

Kata kunci : Karakteristik Pekerjaan, Karakteristik Orgnisasi, Kepuasan Kerja

\section{PENDAHULUAN}

Dewasa ini tingkat persaingan dalam dunia usaha menjadi semakin tinggi. Untuk dapat bertahan dan berkembang dalam kondisi tersebut, suatu perusahaan harus bisa mengembangkan dan mengolah sumber daya yang dimiliki perusahaan untuk menjaga keberlangsungan jalannya

perusahaan dan mencapai tujuan perusahaan.
Sumber daya manusia adalah salah satu aset berharga harus terus dikembangkan dan dipelihara oleh perusahaan, karena tak seperti mesin yang selalu melakukan aktivitas yang sama tiap waktu, manusia selalu mengalami perubahan dan perkembangan, karena perubahan yang terjadi tersebut akan menimbulkan berbagai jenis tantangan yang harus dihadapi dan 
JURNAL PLANS

Penelitian Ilmu Manajemen \& Bisnis

Vol. 10 No. 1 Maret 2015

diatasi dengan baik. Pencapaian tujuan perusahaan akan terlaksana bila sumber daya manusianya menunjukkan produktivitas kerja yang tinggi.

Menurut Gomes (2003:3)

"tugas manajemen sumber daya manusia berkisar dengan upaya mengelola unsur manusia dengan segala potensi yang dimilikinya harus dilakukan seefektif mungkin sehingga dapat diperoleh sumber daya manusia yang puas (satisfied) dan memuaskan (satisfactory) bagi organisasi”. Dari uraian diatas dapat diketahui bahwa manajemen sumber daya manusia memiliki tugas untuk menggali dan mengelola segala potensi yang dimiliki oleh karyawan sehingga memiliki pengaruh yang positif bagi karyawan maupun perusahaan dalam kegiatan operasional dan pencapaian tujuan perusahaan.

Perusahaan tidak hanya menuntut para karyawan untuk melakukan yang terbaik bagi perusahaan tetapi perusahaan juga harus memperhatikan hal-hal apa saja yang dapat menimbulkan rasa nyaman, senang, dan semangat di dalam diri para karyawan di dalam bekerja dan menyelesaikan pekerjaannya. Hal yang penting diperhatikan dalam pemeliharaan hubungan tersebut antara lain adalah kepuasan kerja para karyawan.

Kepuasan kerja merupakan perbandingan antara apa yang dirasakan dan diperoleh oleh seseorang dibandingkan dengan apa yang seharusnya dirasakan dan diperolehmya dari suatu pekerjaan. Wujud dari kepuasan kerja dapat diindikasikan dengan tingkat kerajinan karyawan, tingkat absensi yang rendah, tidak adanya keluh kesah dan jumlah karyawan yang berhenti secara sepihak atau turnover karyawan rendah. (Firman, 2011).

Tujuan perusahaan akan dengan mudah tercapai jika karyawan memperoleh kepuasan kerja mereka. Adanya kepuasan dalam bekerja akan menimbulkan motivasi dalam diri karyawan untuk berprestasi secara optimal demi kemajuan sebuah organisasi yang sedang dinaunginya dan apabila semua karyawan merasakan adanya kepuasan kerja, maka akan berdampak positif bagi kinerja organisasi secara keseluruhan. Mengingat arti pentingnya kepuasan kerja karyawan dalam organisasi, maka setiap organisasi harus meningkatkan kepuasan kerja karyawannya.

Terdapat banyak aspek yang dapat mempengaruhi kepuasan karyawan yang salah satunya yaitu aspek pekerjaan dimana pekerjaan yang diterima tidak memberikan kesempatan untuk menuangkan ide serta kemampuannya, terlalu membosankan atau terlalu berat bagi karyawan serta tidak ada umpan balik yang sesuai atas pekerjaannya dan aspek organisasi dimana karyawan tersebut bekerja, perilaku pemimpin dalam mengatur bawahannya dan lingkungan kerja yang memberikan kenyamanan atau tidak dalam bekerja.

Wexly dan Yulk ( dalam Syafitri, 2013:3) menyatakan masalah kepuasan kerja sangat tergantung pada tiga komponen yaitu karakteristik individu sebagai pelaksana pekerjaan, karakteristik pekerjaan yang dilakukan dan karkateristik organisasi tempat individu tersebut bekerja. 
JURNAL PLANS

Penelitian Ilmu Manajemen \& Bisnis

Vol. 10 No. 1 Maret 2015

Karakteristik pekerjaan merupakan hal penting yang mendorong produktivitas dan kepuasan kerja karyawan yang dirancang untuk memberikan peranan penting dalam kesuksesan dan kelangsungan hidup perusahaan. Pekerjaan yang dirancang dengan baik akan memudahkan karyawan dalam bekerja sehingga mampu menarik dan mempertahankan tenaga kerja dan memberikan motivasi untuk menghasilkan produk dan jasa yang berkualitas.

Karakteristik pekerjaan seorang karyawan jelas terlihat dari desain pekerjaan seorang karyawan. Desain pekerjaan menentukan bagaimana pekerjaan dilakukan oleh karena itu sangat mempengaruhi perasaan karyawan terhadap sebuah pekerjaan, seberapa pengambilan keputusan yang dibuat oleh karyawan kepada pekerjaannya dan seberapa banyak tugas yang harus diselesaikan oleh karyawan. Semakin besarnya keragaman aktivitas pekerjaan yang dilakukan maka seseorang akan merasa pekerjaannya semakin berarti.

Selain karakteristik pekerjaan, karakteristik organisasi juga berpengaruh terhadap kepuasan kerja karyawan, karakteristik organisasi merupakan suatu kondisi dimana setiap organisasi atau lingkungan kerja mempunyai peraturan kebijakan, system pemberian hadiah dan misi lainnya yang berpengaruh pada setiap karyawan.

Sehingga dapat dikatakan bahwa karakteristik organisasi sangat baik digunakan sebagai peramal kepuasan kerja karyawan. Oleh karena itu karakteristik oerganisasi penting dipertimbangkan dalam menetapkan kebijakan peningkatan kepuasan kerja karyawan (Akbar, 2009).

Bank Muamalat Indonesia Cabang

Utama Pematangsiantar adalah salah satu bank umum yang menerapkan prinsip Syariah Islam dalam menjalankan operasionalnya yang telah memiliki kantor cabang di beberapa daerah seperti Aek kanopan, Indrapura, Kisaran, Perdagangan, dan Tanjungbalai. Bank Muamalat Indonesia cabang utama Pematangsiantar adalah sebuah perusahaan perbankan besar yang tidak terlepas dari masalah kepuasan kerja karyawannya.

Berdasarkan observasi awal penulis dari hasil wawancara dengan beberapa karyawan Bank Muamalat Indonesia cabang utama Pematangsiantar, terdapat fenomena mengenai ketidakpuasan kerja karyawannya, yaitu terjadi adanya keluh kesah karyawan mengenai pekerjaannya, ada kecenderungan bahwa karyawan melakukan pekerjaan yang sama, sederhana, dan cenderung berulang-ulang. Kondisi ini jelas akan menyebabkan rasa kejenuhan atau kebosanan, serta ada indikasi bahwa manajemen tidak sepenuhnya memberi kebebasan pada karyawannya untuk menangani tugas-tugas yang lebih kompleks dan bervariasi, sehingga karyawan tidak dapat menunjukkan daya inisiatif dan mandiri dalam menyelesaikan pekerjaan

Indikasi

ketidakpuasan karyawan juga timbul dari adanya keluhan terhadap kesejahteraan terutama masalah promosi jabatan yang membutuhkan waktu lama dan kurang objektif.

\section{METODE PENELITIAN \\ Lokasi Penelitian}

Penelitian ini dilaksanakan pada PT. Bank Muamalat Indonesia, Tbk. Kantor Cabang Utama Pematangsiantar, Jalan Sangnawaluh 
JURNAL PLANS

Penelitian Ilmu Manajemen \& Bisnis

Vol. 10 No. 1 Maret 2015

komplek Megaland Blok A No. 6-7, Pematangsiantar.

\section{Populasi dan Sampel}

Dalam penelitian ini populasi yang digunakan adalah seluruh karyawan yang terdapat pada PT. Bank Muamalat Indonesia, Tbk. Kantor Cabang Utama Pematangsiantar yang berjumlah 32 orang. Sampel dalam penelitin ini, seluruh Karyawan PT. Bank Muamalat Indonesia, Tbk. Kantor Cabang Utama Pematangsiantar yang berjumlah 32 orang akan dijadikan sampel.

\section{Variabel Penelitian dan Defenisi Operasional Variabel Penelitian}

Adapun yang menjadi variabel dalam penelitian ini adalah sebagai berikut:

1. Variabel bebas $(\mathrm{X})$

a. $\left(\mathrm{X}_{1}\right)$ Karakteristik Pekerjaan

b. $\left(\mathrm{X}_{2}\right)$ Karakteristik Organisasi

2. Variabel terikat (Y) : Kepuasan Kerja

\section{Defenisi Operasional}

Untuk menghindari kesalahan persepsi tentang variabel penelitian ini, penulis memberikan defenisi operasional sebagai berikut :

1. Karakteristik Pekerjaan (X1)

Karakteristik pekerjaan adalah sifat internal yang berbeda antara jenis pekerjaan yang satu dengan yang lainnya yang merupakan inti pekerjaan pada PT.Bank Muamalat Indonesia Tbk. Kantor Cabang Utama Pematangsiantar yang berisikan sifatsifat tugas yang ada dalam semua pekerjaan dari perusahaan yang menimbulkan rasa dihargai dan dibutuhkan dalam perusahaan dan akan berdampak pada rasa puas karyawan terhadap pekerjaan.

Indikator dari karakteristik pekerjaan yang digunakan pada penelitian ini antara lain adalah:
a. Keragaman keterampilan atau variasi pekerjaan
b. Identitas tugas
c. Signifkansi tugas
d. Otonomi
e. Umpan balik

2. Karakteristik Organisasi (X2)

Karakteristik organisasi adalah suatu kondisi dimana PT.Bank Muamalat Indonesia Kantor Cabang Utama Pematangsiantar memiliki

peraturan,kebijakan,system

pemberian hadiah dan misi lainnya yang mempengaruhi setiap karyawan.

Indikator dari karakteristik organisasi yang digunakan dalam penelitian ini antara lain :

a. Perilaku Pemimpin

b. Lingkungan Kerja

3. Kepuasan Kerja (Y)

Kepuasan kerja adalah suatu perasaan positif yang timbul dari dalam diri karyawan yang disebabkan oleh hasil pencapaian pekerjaan dan lingkungan kerja pada PT.Bank Muamalat Indonesia Tbk. Kantor Cabang Utama Pematangsiantar.

Indikator-indikator dari kepuasan kerja yang digunakan dalam penelitian ini antara lain:
a. Pembayaran seperti gaji dan upah
b. Pekerjaan itu sendiri
c. Rekan kerja
d. Promosi
e. Penyeliaan (supervisi) 
Teknis Analisis Data

Analisis Regresi Linear Berganda

Analisis Regresi digunakan untuk mengetahui seberapa besar pengaruh variable X (Karakteristik Pekerjaan dan Karakteristik Organisasi) terhadap variabel Y (Kepuasan Kerja).

Dalam penelitian ini analisis regresi yang digunakan adalah analisis regresi linear berganda dengan bentuk persamaan:

Dimana:

$$
\mathrm{Y}=\mathrm{a}+\mathrm{b}_{1} \mathrm{x}_{1}+\mathrm{b}_{2} \mathrm{x}_{2}+\mathrm{e}
$$

$$
\begin{array}{ll}
\mathrm{Y} & =\text { Kepuasan Kerja } \\
\mathrm{a} & =\text { Konstanta } \\
\mathrm{X}_{1} & =\text { Karakteristik Pekerjaan } \\
\mathrm{X}_{2} & =\text { Karakteristik Organisasi } \\
\mathrm{b}_{1} & =\text { Koefisien Karakteristik } \\
& \text { Pekerjaan } \\
\mathrm{b}_{2} & =\text { Koefisien Karakteristik } \\
& \text { Organisasi } \\
\mathrm{e} & =
\end{array}
$$

\section{Pengujian Hipotesis}

\section{Uji t}

Uji t digunakan untuk menguji secara parsial apakah variabel bebas $\left(\mathrm{X}_{1}, \mathrm{X}_{2}\right)$ mempunyai pengaruh signifikan terhadap nilai variabel terikat (Y) dengan rumusan hipotesis sebagai berikut:

$\mathrm{H}_{\mathrm{o}}: \mathrm{b}_{1}=\mathrm{b}_{2}=0$, artinya variabel bebas $\left(\mathrm{X}_{1}, \mathrm{X}_{2}\right) \quad$ tidak mempunyai pengaruh signifikan terhadap variabel terikat $(\mathrm{Y})$.

$\mathrm{Ha}: \mathrm{b}_{1} \neq \mathrm{b}_{2} \neq 0$ artinya variabel bebas (X1, X2) memiliki pengaruh yang signifikan terhadap variabel terikat (Y).

Kriteria pengambilan keputusan:

Ho diterima jika $t_{\text {hitung }}<t_{\text {tabel, }}$, pada $\alpha=$ $5 \%$
Ha diterima jika $t_{\text {hitung }}>t_{\text {tabel }}$, pada $\alpha=$ $5 \%$

untuk $\begin{gathered}\text { Adapun rumus yang digunakan } \\ \text { menguji masing-masing }\end{gathered}$ hipotesis ini adalah dengan rumus uji $t$ parsial (Ridwan 2007:125), yaitu:

$$
t_{\text {hitung }}=\frac{r \sqrt{n-2}}{\sqrt{n-r^{2}}}
$$

Dimana :

$\mathrm{t}=$ Signifikan parsial

$\mathrm{r}=$ Koefisien korelasi parsial

$\mathrm{n}=$ Jumlah sampel/responden

\section{Uji F}

Uji F untuk menguji hipotesis yang diajukan rumusan hipotesis sebagai berikut:

$$
\begin{aligned}
\mathrm{H}_{\mathrm{o}}: \mathrm{b}_{1}=\mathrm{b}_{2}=0, & \text { artinya variabel bebas } \\
& \left(\mathrm{X}_{1}, \mathrm{X}_{2}\right) \text { secara serentak } \\
& \text { tidak ada pengaruh } \\
& \text { signifikan terhadap } \\
& \text { variabel terikat }(\mathrm{Y}) \text {. } \\
\mathrm{Ha}: \mathrm{b}_{1} \neq \mathrm{b}_{2} \neq 0 & \text { artinya variabel bebas } \\
& (\mathrm{X} 1, \mathrm{X} 2) \text { secara serentak } \\
& \text { terdapat pengaruh yang } \\
& \text { signifikan terhadap } \\
& \text { variabel terikat }(\mathrm{Y}) .
\end{aligned}
$$

Kriteria Pengambilan keputusan:

Ho diterima jika $F_{\text {hitung }}<\mathrm{F}_{\text {tabel, }}$, pada $\alpha$ $=5 \%$

Ha diterima jika $F_{\text {hitung }}>F_{\text {tabel, }}$ pada $\alpha=$ $5 \%$

Adapun rumus yang digunakan untuk mengetahui tingkat signifikansi variabel $\mathrm{X}_{1}$ dan $\mathrm{X}_{2}$ secara bersamasama terhadap variabel $\mathrm{Y}$ digunakan rumus uji $F$ regresi (Sugiyono, 2006:190), yaitu:

$$
F h=\frac{R^{2} / k}{\left(1-R^{2}\right) /(n-k-1)}
$$

Dimana:

$\mathrm{R}=$ koefisien korelasi ganda

$\mathrm{k}=$ jumlah variabel independen

$\mathrm{n}=$ jumlah anggota sampel 
Koefisien Determinasi $\left(\mathbf{R}^{2}\right)$

Dari perhitungan $r$ (korelasi) dapat dilihat hubungan variabel bebas $\left(\mathrm{X}_{1}\right.$ dan $\left.\mathrm{X}_{2}\right)$ dan variabel terika $(\mathrm{Y})$ positif atau negatif hubungan tersebut. Determinan digunakan untuk melihat kontribusi variabel bebas $\left(\mathrm{X}_{1}, \mathrm{X}_{2}\right)$ terhadap variabel terikat.

\section{HASIL PENELITIAN DAN PEMBAHASAN}

\section{Hasil Penelitian}

\section{Analisis Regresi Berganda}

Model regresi ganda dengan 1 Variabel dependen (Y) yaitu variabel Kepuasan kerja dan 2 variabel independen (X) yaitu variabel Karakteristik pekerjaan $\left(\mathrm{X}_{1}\right)$, dan Karakteristik organisasi $\left(\mathrm{X}_{2}\right)$ adalah sebagai berikut

$$
\hat{\mathbf{Y}}=\mathbf{a}+\mathbf{b}_{1} \mathbf{X}_{1}+\mathbf{b}_{2} \mathbf{X}_{2}+\mathbf{e}
$$

Untuk menguji hipotesis yang menyatakan terdapat pengaruh Karakteristik pekerjaan $\left(\mathrm{X}_{1}\right)$, Karakteristik organisasi $\left(\mathrm{X}_{2}\right)$ terhadap Kepuasan kerja (Y) digunakan analisis regresi ganda.

Berdasarkan hasil perhitungan diperoleh hasil persamaan regresi ganda adalah sebagai berikut :

Tabel 1. Hasil Perhitungan Regresi Linear Berganda

\begin{tabular}{|c|c|c|c|c|c|}
\hline \multirow[t]{2}{*}{ Model } & \multicolumn{2}{|c|}{$\begin{array}{l}\text { Unstandardized } \\
\text { Coefficients }\end{array}$} & $\begin{array}{l}\text { Standardized } \\
\text { Coefficients }\end{array}$ & \multirow[t]{2}{*}{$\mathrm{t}$} & \multirow[t]{2}{*}{ Sig. } \\
\hline & $B$ & $\begin{array}{l}\text { Std. } \\
\text { Error }\end{array}$ & Beta & & \\
\hline (Constant) & 240 & 4.500 & & .053 & .958 \\
\hline $\mathrm{X} 1$ & .531 & 155 & .448 & 3.435 & .002 \\
\hline $\mathrm{X} 2$ & .609 & .170 & .467 & 3.580 & .001 \\
\hline
\end{tabular}

a. Dependent Variable: $Y$

Dari data hasil SPSS di atas dapat dijelaskan sebagai berikut :

$$
\begin{aligned}
& \hat{\mathbf{Y}}=\mathbf{0 , 2 4 0}+\mathbf{0 , 5 3 1} \mathrm{X}_{1}+\mathbf{0 , 6 0 9} \mathrm{X}_{2}+\mathrm{e} \\
& \text { - Konstan sebesar 0,240 }
\end{aligned}
$$$$
\text { menyakan bahwa jika tidak ada }
$$

variabel $X$, maka kepuasan kerja adalah sebesar 0,240 (asumsi faktor lain konstan).

- Koefisien regresi variabel $X_{1}$ sebesar 0,531 menyatakan bahwa setiap terjadi perubahan karakteristik pekerjaan 1\% akan mempengaruhi kepuasan kerja sebesar 0,531 (asumsi faktor lain konstan).

- Koefisien regresi variabel $X_{2}$ sebesar 0,609 menyatakan bahwa setiap terjadi peningkatan karakteristik organisasi $\quad 1 \% \quad$ akan mempengaruhi kepuasan kerja sebesar 0,609 (asumsi faktor lain konstan).

\section{Uji Hipotesis}

\section{Uji Simultan Menggunakan Uji-F}

Uji hipotesis secara simultan untuk mengetahui apakah model regresi sudah benar atau tidak. Uji hipotesis ini menggunakan taraf signifikan, dan uji ini diperoleh dari

\begin{tabular}{|c|c|c|c|c|c|}
\hline Model & $\begin{array}{c}\text { Sum of } \\
\text { Square } \\
\text { s }\end{array}$ & $\begin{array}{l}D \\
f\end{array}$ & $\begin{array}{c}\text { Mean } \\
\text { Squar } \\
\text { e }\end{array}$ & $F$ & Sig. \\
\hline $\begin{array}{cc} & \begin{array}{c}\text { Regressi } \\
\text { on }\end{array} \\
1 & \text { Residual } \\
& \text { Total }\end{array}$ & $\begin{array}{c}586.25 \\
9 \\
387.93 \\
2 \\
974.19 \\
2\end{array}$ & $\begin{array}{l}2 \\
2 \\
9 \\
3 \\
1\end{array}$ & $\begin{array}{c}293.13 \\
0 \\
13.377\end{array}$ & $\begin{array}{c}21.91 \\
3\end{array}$ & .000 \\
\hline
\end{tabular}
tabel ANOVA berikut ini :

Tabel 2. Hasil Uji Perhitungan Uji F

a. Dependent Variable: $Y$

b. Predictors: (Constant), X2, X1

Dari hasil pengujian terhadap uji Anova atau $F$ test seperti yang ditampilkan diatas diperoleh nilai $\mathrm{F}$ hitung sebesar 21,913 pada taraf $\alpha=$ 0,05. Adapun $F_{\text {tabel }}$ diperoleh dengan rumus df1 $=\mathrm{k}-1 ; \mathrm{df} 2=\mathrm{n}-\mathrm{k}(2 ; 29)$ adalah 3,33. Dengan demikian F hitung 
JURNAL PLANS

Penelitian Ilmu Manajemen \& Bisnis

Vol. 10 No. 1 Maret 2015

$>\mathrm{F}$ tabel atau 21,913 > 3,33 dengan level of significant $\quad(\alpha) 0,000<$ 0,05 yang berarti bahwa variable karakteristik pekerjaan dan karakteristik organisasi secara bersama-sama (simultan) berpengaruh terhadap kepuasan kerja karyawan pada PT. Bank Muamalat Indonesia Kantor Cabang Utama Pematangsiantar, Artinya hipotesis diterima.

\section{Uji Parsial (Uji t)}

Metode dalam penentuan $t$ tabel menggunakan ketentuan tingkat signifikan $5 \%$, dengan $\mathrm{df}=\mathrm{n}-\mathrm{k}-1$ (pada penelitian ini $(\mathrm{df}=32-2-1=29)$, sehingga didapat nilai $t$ tabel sebesar 1,699. Hasil dari pengujian parsial adalah sebagai berikut:

Tabel 3. Nilai t Hitung

\begin{tabular}{|l|l|l|l|l|}
\hline Variabel & $\begin{array}{l}\mathbf{t} \\
\text { hitung }\end{array}$ & $\begin{array}{l}\mathbf{t} \\
\text { tabel }\end{array}$ & Signifikan & Keputusan \\
\hline $\begin{array}{l}\text { Karakteristik } \\
\text { Pekerjaan }\left(\mathrm{X}_{1}\right)\end{array}$ & 3,435 & 1,699 & 0,002 & Signifikan \\
\hline $\begin{array}{l}\text { Karakteristik } \\
\text { Organisasi }\left(\mathrm{X}_{2}\right)\end{array}$ & 3,580 & 1,699 & 0,001 & Signifikan \\
\hline
\end{tabular}

Dari Tabel 3. di atas dapat dijelaskan bahwa :

1. Karakteristik berpengaruh positif dan signifikan terhadap Kepuasan Kerja Karyawan dengan nilai $\mathrm{t}_{\text {hitung }}=3,435>\mathrm{t}_{\text {tabel }}=1,699$ dan probabilitas 0,002 pada tingkat signifikansi 5\%. Hal ini berarti semakin meningkat karakteristik pekerjaan, maka kepuasan kerja karyawan akan meningkat.

2. Karakteristik organisasi berpengaruh positif dan signifikan terhadap Kepuasan kerja karyawan dengan nilai $t_{\text {hitung }}=3,580>t_{\text {tabel }}=1,699$ dan probabilitas 0,001 pada tingkat signifikansi $5 \%$. Hal ini berarti semakin meningkat karakteristik organisasi yang diberikan perusahaan, maka semakin meningkat kepuasan kerja karyawan.

\section{Uji Koefisien Determinasi (Uji $\mathbf{R}^{\mathbf{2}}$ )}

Determinan digunakan untuk mengetahui seberapa besar variabel independen mampu menjelaskan

Model Summary ${ }^{\mathrm{D}}$

\begin{tabular}{|c|c|c|c|c|}
\hline Model & $\mathrm{R}$ & $\begin{array}{c}\mathrm{R} \\
\text { Square }\end{array}$ & $\begin{array}{c}\text { Adjusted } \\
\mathrm{R} \\
\text { Square }\end{array}$ & $\begin{array}{c}\text { Std. Error } \\
\text { of the } \\
\text { Estimate }\end{array}$ \\
\hline 1 & $.776^{\mathrm{a}}$ & .602 & .574 & 3.6574557 \\
\hline
\end{tabular}

a. Predictors: (Constant), X2, X1

b. Dependent Variable: $Y$

pengaruh variabel dependen.

Tabel 4. R Square

Dari tabel diatas, angka R sebesar 0,776 menunjukkan bahwa korelasi atau hubungan yang kuat antara variabel independen (karakteristik pekerjaan dan karakteristik organisasi) dengan variabel dependen (kepuasan kerja). Koefesien Determinasi ( $\mathrm{R}$ square) sebesar 0,602 . Nilai 0,602 ini menunjukkan bahwa variabel kepuasan kerja (Y) dapat dijelaskan oleh variabel karakteristik pekerjaan $\left(\mathrm{X}_{1}\right)$ dan karakteristik organisasi $\left(\mathrm{X}_{2}\right)$ secara bersama sama sebesar $60,2 \%$ dan sisanya $39,8 \%$ dipengaruhi oleh variabel lain diluar model penelitian.

\section{Pembahasan Hasil Penelitian Pengaruh Karakteristik Pekerjaan Terhadap Kepuasan Kerja}

Dengan melihat hasil penelitian yang dilakukan, ada pengaruh yang signifikan antara karakteristik pekerjaan terhadap kepuasan kerja karyawan. Hal ini dapat dilihat dari 
JURNAL PLANS

Penelitian Ilmu Manajemen \& Bisnis

Vol. 10 No. 1 Maret 2015

nilai koefisien Regresi Karakteristik pekerjaan dengan uji parsial (uji t) dengan nilai t hitung 3,435 lebih besar dari $t$ tabel 1,699 pada tingkat signifikansi signifikansi 0,002 yang berarti signifikan untuk menilai kepuasan kerja karena $<5 \%$, maka hipotesis diterima. Artinya terdapat pengaruh yang positif dan signifikan antara karakteristik pekerjaan secara parsial terhadap kepuasan kerja karyawan PT. Bank Muamalat Indonesia Tbk. Kantor cabang Utama Pematangsiantar. Hal ini seperti yang diungkapkan Robbins (2008:240) bahwa karakteristik perkerjaan mampu menciptakan kondisi yang tidak membosankan bagi karyawan akan menciptakan perasaan senang dan puas terhadap pekerjaan.

Hasil penelitan ini mendukung penelitian Panudju (2003) yang membuktikan bahwa variabel variabel dalam karakteristik pekerjaan yaitu otonomi,variasi pekerjaan, identitas tugas, signifikasi tugas dan umpan balik secara bersama sama berpengaruh terhadap pendekatan kepuasan kerja. Serta mendukung penelitian Syafitri (2013) yang menyimpulkan bahwa karakterisrik pekerjaan mempengaruhi kepuasan kerja karyawan.

Karakteristik pekerjaan secara langsung mempengaruhi kepuasan kerja karyawan. Karakteristik pekerjaan dalam menyelesaikan pekerjaan meliputi pertambahan tanggung jawab,tugas yang lebih jelas, serta kebebasan dalam perusahaan dan akan dampak pada rasa puas terhadap pekerjan yang di peroleh dari ragam keahlian, identifikasi tugas,otonomi dan umpan balik yang akan mempengaruhi kepuasan kerja karyawan.

\section{Pengaruh Karakteristik Organisasi Terhadap Kepuasan Kerja}

Dengan melihat hasil penelitian yang dilakukan, ada pengaruh yang signifikan antara karakteristik organisasi terhadap kepuasan kerja karyawan. Hal ini dapat dilihat dari nilai koefisien Regresi Karakteristik Organisasi Hasil perhitungan diperoleh angka $t$ hitung sebesar 3,580 dengan angka signifikansi 0,001. Dengan demikian sig penelitian lebih kecil dari 0,05 maka hipotesis diterima. Artinya terdapat pengaruh yang positif dan signifikan antara karakteristik organisasi secara parsial terhadap kepuasan kerja karyawan PT. Bank Muamalat Indonesia Tbk. Kantor cabang Utama Pematangsiantar.

Hasil penelitan ini mendukung penelitian yang dilakukan oleh Akbar (2009) yang menyimpulkan bahwa variabel karakterteristik organisasi memberikan pengaruh terbesar dibandingkan variabel lain dalam penelitiannya terhadap kepuasan kerja.

Karakteristik organisasi sangat baik digunakan sebagai peramal kepuasan kerja karyawan. Perilaku pemimpin yang bijaksana terhadap karyawannya dan lingkungan kerja yang nyaman akan mempengaruhi kepuasan kerja karyawannya, yang dapat dilihat dari meningkatnya produktivitas kerja, turunnya tingkat absensi serta meningkatkan semangat dan loyalitas kerja karyawan. Pengaruh Karakteristik Pekerjaan
dan Karakteristik Organisasi
Terhadap Kepuasan Kerja 
Vol. 10 No. 1 Maret 2015

Dengan melihat hasil penelitian yang dilakukan, ada pengaruh yang signifikan antara karakteristik pekerjaan dan karakteristik organisasi terhadap kepuasan kerja karyawan. Hal ini dapat dilihat dari nilai perhitungan analisis regresi berganda dengan perhitungan $\hat{\mathbf{Y}}=\mathbf{0 , 2 4 0}+\mathbf{0 , 5 3 1}$ $X_{1}+0,609 X_{2}+e$, yang artinya :

- Konstan sebesar 0,240 menyakan bahwa jika tidak ada variabel $\mathrm{X}$, maka kepuasan kerja adalah sebesar 0,240 (asumsi faktor lain konstan).

- Koefisien regresi variabel $X_{1}$ sebesar 0,531 menyatakan bahwa setiap terjadi perubahan karakteristik pekerjaan 1\% akan mempengaruhi kepuasan kerja sebesar 0,531 (asumsi faktor lain konstan).

- Koefisien regresi variabel $X_{2}$ sebesar 0,609 menyatakan bahwa setiap terjadi peningkatan karakteristik organisasi $\quad 1 \% \quad$ akan mempengaruhi kepuasan kerja sebesar 0,609 (asumsi faktor lain konstan).

Hal ini juga dapat dilihat dari nilai perhitungan uji-F yaitu sebesar 21,913 dengan $\mathrm{f}$ tabel 3,33 yang artinya $F_{\text {hitung }}>F_{\text {tabel }}$ dengan level of significant

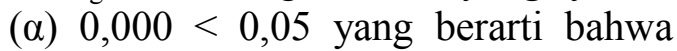
variable karakteristik pekerjaan dan karakteristik organisasi secara bersama-sama (simultan) berpengaruh terhadap kepuasan kerja karyawan pada PT. Bank Muamalat Indonesia Kantor Cabang Utama Pematangsiantar, Artinya hipotesis diterima.

Dari perhitungan koefisien koefisien determinan diketahui besarnya angka $\mathrm{R}^{2}$ adalah sebesar
0,602 . Nilai tersebut ini menunjukkan bahwa variabel kepuasan kerja (Y) dapat dijelaskan oleh variabel karakteristik pekerjaan $\left(\mathrm{X}_{1}\right)$ dan karakteristik organisasi $\left(\mathrm{X}_{2}\right)$ secara bersama sama sebesar $60,2 \%$ dan sisanya $39,8 \%$ dipengaruhi oleh faktor lain diluar model penelitian ini.

Hasil penelitan ini mendukung penelitian Sudarsono (2011) yang membuktikan bahwa karakteristik pekerjaan dan karakterteristik organisasi memberikan pengaruh terhadap kepuasan kerja secara bersama-sama. Serta penelitian yang dilakukan oleh Subyantoro (2009) yang menyatakan bahwa karakteristik pekerjaan dan karakteristik organisasi mempengaruhi kepuasan kerja baik pengaruh langsung maupun pengaruh secara tidak langsung.

Berdasarkan hasil penelitian menandakan bahwa kepuasan kerja karyawan PT.Bank Muamalat Indonesia Kantor Cabang Utama Pematangsiantar sangat dipengaruhi oleh karakteristik pekerjaan dan karakteristik organisasi. Hal ini sesuai dengan yang diungkapkan oleh Wexley dan Yulk (dalam Sumantri, 2001) mengemukakan factor-faktor yang mempengaruhi kepuasan kerja dikelompokkan kedalam tiga bagian, yaitu karakteristik pekerjaan, karakteristik situasional (organisasi), dan karakteristik individu. Menurut Ting dan Yuan (dalam Subyantoro, 2009) kepuasan kerja karyawan dipengaruhi oleh karakteristik individu, karakteristik pekerjaan dan karakteristik organisasi. Hasil penelitianya menunjukkan bahwa karakteristik pekerjaan (kepuasan pembayaran, promosi, kejelasan tugas, 
JURNAL PLANS

Penelitian Ilmu Manajemen \& Bisnis

Vol. 10 No. 1 Maret 2015

signifikansi tugas dan pemanfaatan

keterampilan) secara konsisten

berpengaruh pada kepuasan kerja.

Begitu juga karakteristik organisasi

(komitmen organisasi, hubungan

dengan supervisor dan teman kerja)

secara konsisten berpengaruh terhadap kepuasan kerja. Tetapi karakteristik individu (pelayanan umum, usia, pendidikan, ras dan gender) tidak berpengaruh secara konsisten terhadap kepuasan kerja.

Karakteristik pekerjaan membantu karyawan mendapatkan kepuasan kerjanya, melalui karakteristik pekerjaan karyawan dituntut memiliki ragam keahlian agar dapat menjalankan tugasnya dengan baik, adanya kejelasan tugas sehingga memberikan informasi bagi karyawan dan memudahkan pekerjaannya, tugas yang diberikan sangat penting bagi perusahaan sehingga karyawan merasa dibutuhkan, adanya kewenangan yang membuat karyawan bebas memberikan idenya, dan umpan balik berupa gaji yang pantas dan perhatian dari atasan yang sangat memberikan pengaruh terhadap kepuasan kerja.

Selain karakteristik pekerjaan, faktor karakteristik organisasi juga mempengaruhi kepuasan kerja karyawan. Lingkungan kerja yang nyaman akan memberikan dampak kepada karyawan untuk bekerja dengan baik dan perilaku pemimpin yang bijaksana terhadap karyawannya akan memberikan dampak positif terhadap kepuasan karyawan, sehingga karyawan merasa menjadi bagian yang utuh di dalam organisasi tersebut.

PENUTUP

Kesimpulan
1. Dari hasil penelitian pada PT. Bank Muamalat Indonesia Tbk, Kantor Cabang Utama Pematangsiantar bahwa variabel karakteristik pekerjan berpengaruh secara positif dan signifikan secara parsial terhadap kepuasan kerja karyawan, hal ini dapat dilihat dari nilai koefisien Regresi uji parsial karakteristik pekerjaan sebesar 3,435 dengan signifikansi 0,002 yang berarti signifikan untuk menilai kepuasan kerja karena $<5 \%$, menyatakan bahwa hipotesis diterima.

2. Karakteristik Organisasi berpengaruh secara positif dan singnifikan terhadap kepuasan kerja karyawan. Pengaruh Karakteristik organisasi dengan uji parsial sebesar 3,580 dengan signifikansi 0,001 yang berarti signifikan untuk menilai kepuasan kerja karena nilai signifikan $<5 \%$, menyatakan bahwa hipotesis diterima.

3. Berdasarkan perhitungan uji $t$ (uji parsial) dari kedua variabel independen yaitu karakteristik pekerjaan (X1) dan karkateristik organisasi (X2), variabel karakteristik organisasi (X2) memiliki pengaruh yang lebih besar terhadap kepuasan kerja dibandingkan variabel karakteristik pekerjaan (X1), yaitu sebesar 3,580.

4. Dari hasil penelitian pada PT. Bank Muamalat Indonesia Tbk, Kantor Cabang Utama Pematangsiantar, variabel karakteristik pekerjaan dan 
JURNAL PLANS

Penelitian Ilmu Manajemen \& Bisnis

Vol. 10 No. 1 Maret 2015

karakteristik organisasi secara bersama-sama mempengruhi kepuasan kerja karyawan PT.Bank Muamalat Indonesia Tbk, Kantor Cabang Utama Pematangsiantar, hal ini dapat di lihat dari hasil perhitungan uji-F sebesar 21,913 dengan $\mathrm{f}$ tabel 3,128 yang artinya $\mathrm{F}_{\text {hitung }}>\mathrm{F}_{\text {tabel }}$ dengan level of significant $(\alpha) 0,000<0,05$, menyatakan bahwa hipotesis diterima.

5. Diperoleh nilai $\mathrm{R}^{2}$ sebesar 0,602 ,yang berarti karakteristik pekerjaan dan karakteristik organisasi menjelaskan pengaruh terhadap variabel kepuasan kerja sebesar $60,2 \%$, sedangkan sisanya $39,8 \%$ di jelaskan variabel lain di luar penelitian.

\section{DAFTAR PUSTAKA}

Akbar, Abdi. 2009. "Pengaruh Karakteristik Pekerjaan, Karakteristik Organisasi dan Karakteristik Individu tarhadap Kepuasan Kerja Karyawan Bank Swasta Di Provinsi Sulawesi Selatan". Jurnal, Vol.6. No.2.

Arikunto, S. 2006. Prosedur Penelitian Suatu Pendekatan Praktik, Jakarta : Rineka Cipta.

As'ad, M. 2003. Psikologi Industri: Seri Sumber Daya Manusia. Yogyakarta: Liberty

Firman. 2011. "Pengaruh Karakteristik Pekerjaan Terhadap Kepuasan Kerja Pegawai di Lingkungan Pemkot Payakumbuh". Jurnal Tingkap, Vol.VII, No.2.
Gomes, Faustino Cardoso. 2003 Manajemen Sumber Daya Manusia. Yogyakarta: Penerbit Andi

Handoko T, Hani. 2003. Manajemen Personalia dan Sumber Daya Manusia. Edisi Kedua. Yogyakarta : BPFEYogyakarta

Hasibuan, Malayu S.P. 2003. Manajemen Sumber Daya Manusia. Jakarta: Bumi Aksara Jakarta.

$\begin{array}{lr}\text { Organisasi } & 2007, \\ \text { Motivasi. } & \text { dan } \\ \text { PT.Bumi Aksara } & \end{array}$

Kuncoro, Mudrajad. 2009. Metode Riset untuk Bisnis \& Ekonomi. Jakarta: Erlangga

Luthans, Fred. 2006. Prilaku Organisasi edisi 10. Yogyakarta: ANDI Yogyakarta.

Novita, Sylvia D. 2014. "Pengaruh komunikasi dan pengembangan karir terhadap kepuasan kerja karyawan pada PT. Pelabuhan Indonesia I (Persero) Cabang Belawan". Medan. Universitas Negeri Medan. Skripsi.

Panudju, Agung. 2003, "Pengaruh Kompensasi dan Karakteristik Perkerjaan Terhadap Kepuasan Kerja Karyawan Unit Produksi PT. X Palembang", Jurnal Manajemen \& Bisnis Sriwijaya. Vol. 1 No. 2, Oktober.

Riduwan dan Akdon. 2009. Rumus dan data dalam Analisis Statistika. Bandung: Alfabeta 
Vol. 10 No. 1 Maret 2015

Robbin, Stephen P. 2002. Perilaku Organisasi. Konsep Kontroversi, Aplikasi Jilid 1, Alih bahasa Hadyana Pujaatmaka. Jakarta: PT. Prenhallindo.

Robbins, Stephen P.; Judge, Timothy A. 2008. Perilaku Organisasi buku 1. Jakarta: Salemba empat. Penerjemah Diana angelica

Setiono, Benny Agus. 2001. "Pengaruh Karakteristik Organisai, Karakteristik Individu dan Karakteristik Pekerjaan Terhadap Kinerja Karyawan dalam Aplikasi Admininistrasi”. Media Analisa Masalah Administrasi. Vol.2 No.2 Desember, FIA Hang Tuah, Surabaya.

Siagian, P Sondang. 2001. Manajemen Sumber Daya Manusia. Jakarta : Bumi Aksara

Simamora, Henry, 2004. Manajemen Sumber Daya Manusia (Edisi 3). Yogyakarta: STIE YKPN.

Sinaga, Rimdaniyati. 2013. Pengaruh Kepribadian dan Lingkungan kerja Non Fisik terhadap Kepuasan Kerja Karyawan pada PT. PLN (Persero) unit induk pembangunan jaringan sumatera. Medan. Universitas Negeri Medan. Skripsi.

Sopiah. 2008. Perilaku Organisasional. Yogyakarta: Penerbit Andi
Stoner, James A.F. 2003. Manajemen. Penerjemah Agus maulana dkk. Jakarta. Erlangga.

Subyantoro, Arief. 2009. "Karakteristik Individu,Karakteristik

Pekerjaan, Karakteristik Organisasi dan Kepuasan Kerja Pengurus yang Dimediasi oleh Motivasi Kerja (Studi pada pengurus KUD di Kabupaten Sleman)".Jurnal Manajemen dan Kewirausahaan,Vol.11, NO.1, Maret :11-19.

Sudarsono, Heri. 2010. "Pengaruh Karakteristik Pekerjaan dan Karakteristik Organisasi terhadap Kepuasan Kerja Pegawai pada Puskesmas Kecamatan Sumbermanjing Wetan di Malang". Jurnal Aplikasi Manajemen, Vol.8, No.3, Agustus.

Sugiyono. 2006. Metode Penelitian Bisnis. Bandung: Alfabeta.

Sumantri, Suryana. 2001. Perilaku Organisasi. Bandung : Universitas Padjajaran

Syafitri, Ayu. 2013. Pengaruh Karakteristik Pekerjaan dan Karakteristik Individu Terhadap Kepuasan Kerja Karyawan PT.Manunggal Wiratama Medan. Universitas Negeri Medan. Skripsi.

Thoha, Miftah. 2003. Perilaku Organisasi. Jakarta : Grafindo Persada. 